\title{
Editorial: Service Learning, Educational Innovation and Social Transformation
}

\author{
Robert G. Bringle ${ }^{1 *}$, Miguel A. Santos Rego ${ }^{2}$ and Bibiana Regueiro ${ }^{2}$ \\ ${ }^{1}$ Indiana University Purdue University Indianapolis, Indianapolis, IN, United States, ${ }^{2}$ University of Santiago de Compostela, \\ Santiago de Compostela, Spain
}

Keywords: service-learning, research, community engagement, scholarship, reflection

Editorial on the Research Topic

Service Learning, Educational Innovation and Social Transformation

Originating in North American and expanding around the world, service-learning is a pedagogy that deepens educational outcomes and is aligned with social action. Grounded in the principles of active and experiential learning articulated by Dewey, Lewin, and Piaget, among others (Kolb, 2015), servicelearning advocates for a more comprehensive education for students that includes not only academic learning but also civic learning and personal growth. In addition, it encompasses establishing reciprocal relationships with communities to the benefit of their residents and organizations.

Although the extant literature currently suggests that service-learning gives new meaning to the learning of competences and is a valuable tool in achieving them, there are still many challenges that arise for all agents involved in the process (e.g., residents, social entities, universities, instructors, students). Scholarship and research have historically been two fundamental activities that have shaped servicelearning, but there are still many tensions, contrasts, and challenges that have to be resolved.

Service-learning is intentionally focused on student development and community improvement,

Edited and reviewed by: Stefinee Pinnegar, Brigham Young University, United States

*Correspondence: Robert G. Bringle rbringle@iupui.edu

Specialty section: This article was submitted to Teacher Education, a section of the journal Frontiers in Education

Received: 19 November 2021 Accepted: 09 December 2021

Published: 05 January 2022

Citation:

Bringle RG, Santos Rego MA and Regueiro B (2022) Editorial: Service Learning, Educational Innovation and

Social Transformation.

Front. Educ. 6:818660.

doi: 10.3389/feduc.2021.818660 situating it as a pedagogical strategy with the potential for both educational innovation and social transformation. In addition, just as service-learning also involves continuous reflection that allows connections between learning and action in community settings, scholarship and research on servicelearning provides opportunities for scholars to reflect on and advance the theory and practice of servicelearning.

This special issue of Frontiers in Education is one example of providing an opportunity for scholars to contribute to the development of service-learning. The entries are diverse in terms of institutional contexts, national settings, and theoretical/disciplinary orientations. Most of the manuscripts, like the field in general, reported research focused on student outcomes in service-learning. These manuscripts covered student outcomes across academic learning, careers and professional preparation, civic and democratic orientations to society, student identity, and personal growth. The breadth of these topics illustrates the potential for service-learning to contribute to different types of learning, thus enriching the educational experiences of students.

Several of the articles captured multidisciplinary orientations to service-learning and others contributed unique theoretical analyses of service-learning. Two articles examined technology-based service-learning (eS-L), a particularly timely topic because the CoVid pandemic resulted in many service-learning courses being converted into eS-L courses. The integration of technology has the potential to improve all servicelearning in the future and for practitioners to re-examine how reflection can be supported by technology, the nature of technology-based civility and civic skills, and technology-supported relationships. Thus, the versatility of service-learning as explored in these articles suggested additional ways in which service-learning can enhance its efficacy and result in change in the university curriculum. 
The scholarship reported in this issue can advance understanding of the processes of optimal course design, implementation, and evaluation as instructors and students work with community partners to reach meaningful outcomes. As such, service-learning has the potential to change work on campus beyond a single course, an isolated practitioner, and a specific community-based activity. Service-learning can be an agent of change more broadly in the university curriculum, in the professional lives of academic staff and instructors, in the relationships that support service-learning, in the lives of students, and in the democratic processes of the campus and communities (Saltmarsh et al., 2009). In this way, service-learning becomes a significant contributor to defining, refining, and redefining the public purposes of institutions of higher

\section{REFERENCES}

Kolb, D. A. (2015). Experiential Learning: Experience as the Source of Learning and Development. 2nd. Ed. Saddle River, NJ: Pearson Education.

Saltmarsh, J., Hartley, M., and Clayton, P. H. (2009). Democratic Engagement White Paper. Boston, MA, New England Resource Center for Higher Education.

Conflict of Interest: The authors declare that the research was conducted in the absence of any commercial or financial relationships that could be construed as a potential conflict of interest. education and their relationships to local, national, regional, and global communities that are increasingly diverse. Strategic institutional support will be needed to build upon the existing practice and scholarship currently existing around the world. Our hope is that the contents of this special issue will contribute to the momentum that currently exists to analyze and expand servicelearning and will transform institutions and their practice to be more engaged, more democratic, and more humane in the future.

\section{AUTHOR CONTRIBUTIONS}

All authors listed have made a substantial, direct, and intellectual contribution to the work and approved it for publication.

Publisher's Note: All claims expressed in this article are solely those of the authors and do not necessarily represent those of their affiliated organizations, or those of the publisher, the editors and the reviewers. Any product that may be evaluated in this article, or claim that may be made by its manufacturer, is not guaranteed or endorsed by the publisher.

Copyright (C) 2022 Bringle, Santos Rego and Regueiro. This is an open-access article distributed under the terms of the Creative Commons Attribution License (CC BY). The use, distribution or reproduction in other forums is permitted, provided the original author(s) and the copyright owner(s) are credited and that the original publication in this journal is cited, in accordance with accepted academic practice. No use, distribution or reproduction is permitted which does not comply with these terms. 